\title{
Colin McPhee and Balinese Music: A Short Bibliography
}

\author{
I Wayan Sudirana \\ Music Department, Institut Seni Indonesia Denpasar, Indonesia \\ email: sudirana.isi@gmail.com.
}

\begin{abstract}
Colin McPhee was a talented pianist and composer who had a deep musicological interest in exploring another musical language. Only a few composers in the western world would have afforded themselves the chance to do exactly the same thing that McPhee did. His life was completely changed by the influence of Balinese music. He published books about music and culture of Bali as well as the aspect of human life in Balinese society. In fact, McPhee's works engaging in and focusing on Balinese culture are a great contribution to the Balinese and a good way of introducing Balinese culture to the world. For the present and future generations of Balinese musicians, Mcphee's works of Balinese music will be standing as an important piece of heritage. The paper is a brief biography of Colin McPhee, focusing mainly on his work as an ethnomusicologist. As a Balinese musician and composer, I am primarily interested in his works as they relate to Balinese culture. I will also introduce some of his western music compositions that were inspired by the gamelan ${ }^{1}$ music of Bali. I hope that by doing this project, I will gain a better understanding and insight into what Colin McPhee has done for my music as well as for the field of ethnomusicology in general.
\end{abstract}

Keywords: Colin McPhee, Balinese gamelan, composition

\section{ABSTRAK}

Colin McPhee adalah seorang pianis dan komposer berbakat yang memiliki minat musik yang mendalam dalam mengeksplorasi bahasa musik lainnya. Hanya beberapa komposer di dunia barat yang akan memberi kesempatan untuk melakukan hal yang persis sama seperti yang dilakukan McPhee. Hidupnya benarbenar berubah oleh pengaruh musik Bali. Dia menerbitkan buku-buku tentang musik dan budaya Bali serta aspek kehidupan manusia dalam masyarakat Bali. Bahkan, karya McPhee yang terlibat dan berfokus pada budaya Bali merupakan kontribusi besar bagi orang Bali, dan cara yang baik untuk memperkenalkan budaya Bali kepada dunia. Untuk generasi sekarang dan generasi mendatang musisi Bali, karyakarya musik Mcphee akan berdiri sebagai bagian penting dari warisan budaya untuk Bali dan dunia. Makalah ini adalah biografi singkat Colin McPhee, yang utamanya berfokus pada karyanya sebagai seorang etnomusikolog. Sebagai seorang musisi dan komposer Bali, saya terutama tertarik pada karya-karyanya karena mereka berhubungan dengan budaya Bali. Saya juga akan memperkenalkan beberapa komposisi musik baratnya yang terinspirasi oleh musik gamelan Bali. Saya berharap

\footnotetext{
${ }^{1}$ Gamelan is an Indonesian name for an orchestra of gongs and other percussion instruments.
} 
bahwa dengan penulisan paper ini, saya akan mendapatkan pemahaman dan wawasan yang lebih baik tentang apa yang telah dilakukan Colin McPhee untuk musik saya sendiri, serta untuk bidang etnomusikologi pada umumnya.

Keywords: Colin McPhee, Gamelan Bali, komposisi.

\section{BACKGROUND}

When I was studying at ISI (Institut Seni Indonesia) Denpasar, the Institute of Arts in Bali, my teacher introduced me to a name of composer, Colin McPhee, who spent his time studying Balinese culture in Sayan, a small village outside of $\mathrm{Ubud}^{2}$ in central Bali. I wanted to study more about him and what he did to promote my culture among scholars in the world.

As a Balinese person and on behalf of the Balinese community, I want to give my respect to Colin McPhee for all his works on behalf of Balinese culture, especially his masterpiece Music in Bali. In addition, I want to know more about his life as well as his research in other kinds of music or cultures in the world, and possibly to define the influence of Balinese music on his compositions.

\section{METHOD}

The following paper is a brief biography of the Canadian composer and pianist, Colin McPhee, focusing mainly on his work as an ethnomusicologist. As a Balinese musician and composer, I am primarily interested in his works as they relate to Balinese culture. I will also introduce some of his western music compositions that were inspired by the gamelan ${ }^{3}$ music of Bali. I hope that by doing this project, I will gain a better understanding and insight into what Colin McPhee has done for my music as well as for the field of ethnomusicology in general.

\footnotetext{
${ }^{2}$ Ubud is a small village in the middle side of Bali that has rich cultural activity. Many scholars decided to stay in this village.

${ }^{3}$ Gamelan is an Indonesian name for an orchestra of gongs and other percussion instruments.
} 


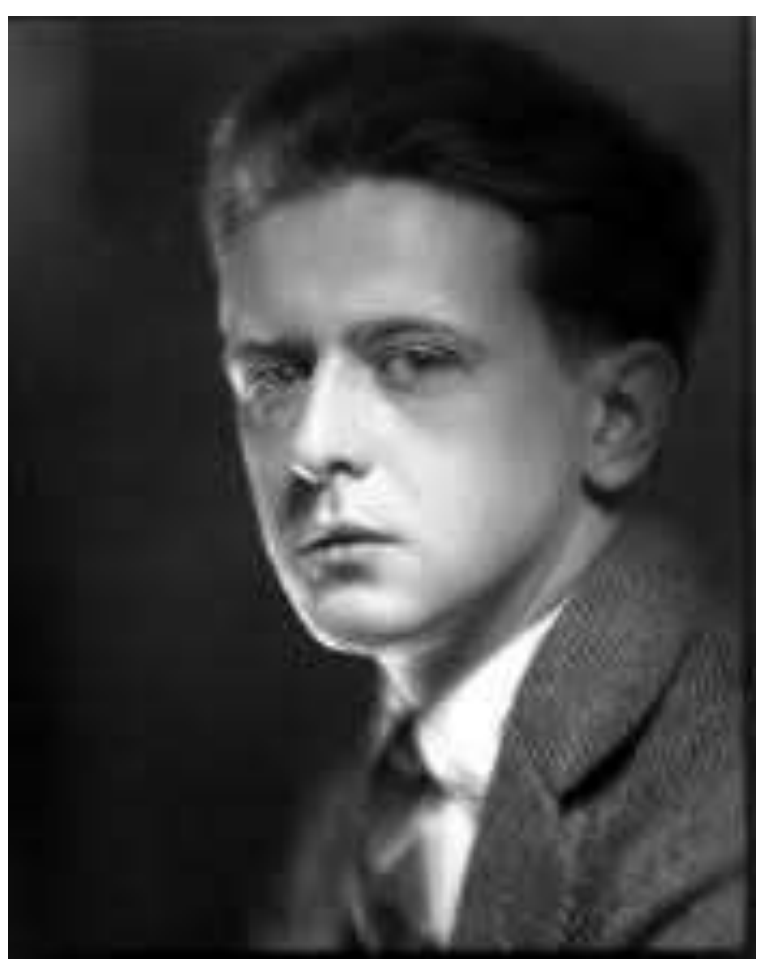

Gambar 1 : Colin McPhee

(Internet archive: https://ethnomusicologyreview.ucla.edu).

\section{DISCUSSION}

Colin McPhee was a composer, pianist, and pioneer researcher on the gamelan music of Bali. He was born in Montreal on March 15, 1900 and raised in Toronto. His family and teachers recognized his talent in music when he was a child. Therefore, his family sent him to study at the Peabody Conservatory in Baltimore, Maryland in 1918. Later, in 1924, he continued to study piano with Isidore Philip and studied composition with Paul Le Flem in Paris. While he studied in Baltimore and Paris, he became a well-known musician in western music and returned to New York to establish himself as an important member of the musical avant-garde. He worked as a composer under the direction of his teacher, Arthur Friedheim who was a pupil of Franz Liszt. During that time, he was also busy performing, touring with the singer Eva Gauthier, playing for contemporary music concerts as well as giving solo 
recitals. Arthur Friedheim (1859-1932), an eminent pianist, wrote in his autobiography:

And the day has dealt kindly with me too, for I have received from far-off Java a letter from a former Toronto pupil, Colin McPhee, perhaps the most gifted pupil I ever had. His innate musical sense, his sturdy application and a striking personality marked him out for a brilliant career on the concert platform. I felt a personal sense of loss when, after I left Canada, he gave up the piano altogether and applied himself entirely to composition. Now he is in Java and other distant lands seeking new inspiration in the relatively unfamiliar native music. Yet I must not criticize him because he has neglected my favorite instrument. Did I not do the same thing when I was his age? (Friedheim, 1961: 256).

Around the late 1920s, while Colin McPhee exploring his talents as a member of the New York Polyhymnia symphony, he became interested in the study and performance of music from different cultures outside of European music. When he discovered newly released recordings of the exotic music of Bali, it ignited an instant desire to perceive what kinds of instruments made such beautiful and intricately textured sounds. The vibrant timbres and complex rhythms of Balinese gamelan completely changed his life. In his book $A$ House in Bali, he wrote:

I was a young composer, recently back in New York after student days in Paris, and the past two years had been filled with composing and the business of getting performances. It was quite by accident that I had heard the few gramophone records that were to change my life completely, bringing me out here in search of something quite indefinable - music or experience, I could not at this moment say (McPhee, 1946: 9).

As a composer, McPhee saw the instruments of the Balinese gamelan as a new resource for creating music, a "crystal, vibrant sound" (Oja, 1984: 3) he had looked for since he was a child, but was ultimately unable to find in the world of western music. To understand this music became an obsession for him. McPhee described clearly the complex sound of gamelan in his letter to Dr. William Mayer after his Bali years (Oja, 1984: 3). In that letter McPhee explained that when he was 12 years old, he composed a piece for a children's percussion band which he had various ideas for sound effects, but the effects were not satisfying his expectations. 
However, ten years later, he tried again incorporating glass wind chimes into a piano concerto, but it was not able to produce the exact sound he wanted. Surprisingly, at the moment he heard Balinese and Javanese music, the sounds that those instruments produced instantly achieved for him that elusive sonority he had looked for. Like others who sought to explore the island, such as the critic and novelist Carl Van Vechten, the Mexican artist Miguel Covarrubias, the painter George Biddle, and Jane Bello (who later become his wife), he sailed to Bali for the first time in 1930.

After staying in a special hotel for foreign guests for a time, Colin McPhee ventured out away from the other visitors and stayed in village of Kedaton, south of Denpasar (capital city of Bali). Balinese musical activity there was unbelievable to him, and people seemed to be very creatively free in their cultural life. In that era, there was a shifting of tradition or artistic centers from the palaces to the village banjar $^{4}$ (Tenzer, 1998: 16). It was changing the way that Balinese people develop their traditions from the community's perspective, though they still paid respect to the courts. Colin McPhee become fascinated with the unique culture of Bali as he started to explore the music had dreamed about. Because the Balinese are mostly a friendly people, he quickly found master Balinese musicians to study and transcribe the music, met friends in a Balinese friendship style ${ }^{5}$ and gathered information from everyone he met. One of them was I Nyoman Kaler, a Balinese musician deeply knowledgeable about the more ancient traditions. Kaler said that 20 years earlier, each palace would have had two orchestras. Outside of the palace would stand one gamelan with great gongs, which was used for ceremonies and to welcome the guest and inside the palace, and there was a little gongs and keyed instruments of delicate tone to play more romantic music. This Gamelan was called gamelan Semara Pegulingan, the gamelan of Semara, God of Love (Young, 1984: 15).

\footnotetext{
${ }_{5}^{4}$ Banjar is a traditional community center in Balinese society.

${ }^{5}$ In Bali, when people already know somebody or foreign who come to Bali for as visitor, Balinese people will directly treat them like their family. However, not all Balinese are friendly, but most of them, in this case, are friendly peoples.
} 
The music of Bali totally changed McPhee's life. In 1931, he returned to Paris to continue his study of western music, but found himself bored with it and decided to go back to Bali for a longer stay. He stayed in Sayan, a mountain village where German artist Walter Spies had settled and built a traditional house. This house became a second home for McPhee as he would live there, on and off, for the next seven years. He made many transcriptions of Balinese music ${ }^{6}$, which helped him to understand the complexity of its construction. He worked to transcribe many of these recordings, and had in his house a piano that he always used to help in his transcriptions. In 1935, he met one of his more important teachers, Wayan Lotring, a brilliant Balinese composer who helped McPhee reorganize a gamelan club in the coastal village of Kuta (McPhee, 1946: 164-165). With Lotring, who made a series of recordings for Odeon in 1928 (McPhee, 1966: 152), he tried to study in depth one type of ensemble in Bali called gamelan pelegongan ${ }^{7}$, particularly in Kuta. McPhee also learned many other things about Lotring's life as a composer as well as studied his music for gamelan pelegongan that was quite unlike anything that McPhee had heard in the island.

At the end of December 1935, Colin McPhee went back to America (Oja, 1984: 7). He brought with him idea of new music that was influenced by the music of Bali, which he had by then studied and engaged in for four years. He was spending some of his time in Mexico, where he came up with an idea to compose a piece for orchestra using ideas of Balinese music in combination with western music and other styles as well. The result of this was a composition called Tabuh-tabuhan (Toccata for Orchestra and Two Pianos), composed in 1936 and first performed by Carlos Chave and the National Orchestra of Mexico City. ${ }^{8}$ This piece was largely inspired by

\footnotetext{
${ }^{6}$ It was very hard for him to record music at that time, because there was no recording equipment and electricity in Bali yet.

${ }^{7}$ Gamelan Pelegongan is one set of ensemble in Bali that is similar like gamelan Semara Peglingan. It usually played to accompany a dance piece called Legong dance. The word pelegongan derived fro the root word "legong". See "Michael Tenzer, Balinese Music, Berkeley and Singapore: Periplus Edition, 1991, and Colin McPhee, Music in Bali, New Haven: Yale University Press, 1966.

${ }^{8}$ See Colin McPhee, Tabuh-tabuhan: toccata for orchestra and 2 pianos, distributed by Hal Leonard, Associated Music, New York, c1960.
} 
the various methods of Balinese gamelan technique. The title was derived from the Balinese word tabuh, which means the mallet used for striking the Balinese instruments, but also refers to different drum rhythms, metric forms and gong punctuations. $^{9}$

In this piece, McPhee mimicked the instrumentation of a Balinese ensemble by using two pianos, celesta, xylophone, marimba, and glockenspiel, to form the core of the orchestra. He called this the "nuclear gamelan". He also considered that this piece was a purely personal work, in that he used Balinese composed motifs, melodies, and rhythms fused with his own western sensibilities to create a new kind of symphony. Douglas Young in his article "Colin McPhee's Music: (II) 'Tabuhtabuhan", said that even though it is composed for a large orchestra, it is not a symphony. Though Tabuh-tabuhan has a definite close relationship with Copland's symphonic dance works, he said that "the superb rhythmic sweep of the first movement culminates in a wonderful series of overlapping entries of an upwardsurging motif, brilliantly orchestrated at different speeds and in a great variety of metrical displacements". The significance of Tabuh-tabuhan is that it was an early example of a composer treating non-Western music seriously in combination with the art music of Europe (Young, 1986: 19).

After McPhee's year of composing Tabuh-tabuhan in Mexico, he continued to write several articles about Indonesia as well as working as a jazz critic. Around 1937, he returned to Bali to continue his research on Balinese music and culture. $\mathrm{He}$ was eager to begin further study of the older music of the island, especially the music that is related to a ritual context. Together with I Made Lebah, ${ }^{10}$ he had a plan to form a group in Sayan for the sole of purpose of reviving the gamelan Semara Pegulingan (McPhee, 1979: 187). This music was very rare in the island, because of the influence of kebyar style, a style that was becoming the most popular, causing

\footnotetext{
${ }^{9}$ Colin McPhee explained this in his prefatory 'Note' to the full score of Tabuh-Tabuhan (eventually published by AMP Icn. 1960).

${ }^{10}$ I Made Lebah was a great musician and performer from the village of peliatan, a small village next to Ubud, who also become McPhee's driver and stayed together with him in Sayan. See Colin McPhee, A House in Bali. New York: John Day, 1979.
} 
villages to upgrade their old ensembles into kebyar instruments. It was McPhee's desire to help encourage the Balinese to maintain the old styles of their own music that were in danger of extinction. The result of this idea was the formation of a children's music association in Sayan village. He gathered all of talented children from Sayan, and provides a teacher from outside of the village to teach them as a group, as well as facilitating them with a set of instruments to learn one particular old style of music that was rare in the island. ${ }^{11}$

By the time he went back to New York at the end of 1938 (because of the prediction of World War II), his "pocket" was already full with research data on music and culture of Bali. He met Benjamin Britten in New York in 1940, and after exposing him to Balinese music, McPhee's transcription for two pianos of Balinese gamelan music have been published through Schirmer's Library of Recorded Music. Under the title of Balinese ceremonial music, this album includes the music of shadow play, arja flute melodies, and the ceremonial music, which open the temple festival. He also arranged Britten's Variations on a Theme of Frank Bridge for two pianos. The particular aspect of Britten's music under consideration is because of the effect of his exposure to the music and theater of Bali and Japan, the former thanks to McPhee. ${ }^{12}$

In 1947, A House in Bali was published, an autobiography of McPhee's life during his time in Bali. This book told the story of how McPhee became interested in Balinese music for the first time by listening to a recordings, how he decided to sail to Bali, how he became fascinated with the culture, music, and the fresh and friendly environment of the village, and primarily what he was doing during five years in Bali. This book is mainly concern about giving the idea or the picture of the Balinese as well as their customs. In the explanation on that idea, he described how dancers, singers, and musicians were trained to be a performer, how they organized performances, how they should obligate to perform at the village temple and how the

\footnotetext{
${ }^{11}$ See Colin McPhee A Club of Small Men, An Asia Book, The John Day Company, New York, 1948.

12 See Michael Tenzer in his Reviewed Works of Britten and the Far East: Asian Influences in the Music of Benjamin Britten by Mervyn Cooke, Asian Music, Vol. 32, No. 1, Tribal Music of India (Autumn, 2000 - Winter, 2001), pp. 190-192.
} 
music related to the culture and religion.

A year after A House in Bali was published, A Club of Small Men, McPhee's other book, was published as well. In this book, McPhee described a group of Balinese children from the mountain village of Sayan, five to eight years old, who wanted to make music as well as adults. They looked on when their fathers played gamelan and wished that later on they could also play like that (McPhee, 1948: 11). By looking at this situation and how the children has a strong desire to have their own group, McPhee helped them to obtain an orchestra as well as find a master teacher, who knew a many repertoire, from other side of the island. They were to become very well known because they were often asked to play in the temple festival. McPhee also provides great photographs and drawings that illustrate the story. $^{13}$

During the 1950s and until 1962, McPhee was busy composing many different pieces for western ensembles, such as Transition for Orchestra, first performed by the Vancouver Symphony Orchestra under the conductor of Irwin Hoffman in 1955, and three scores for documentary films commissioned by the United Nations. His Nocturne for Small Orchestra, premiered by Leopold Stokowski at the Metropolitan Museum of Art, New York in 1958 was a small and delicate work of great diversity, which showed that McPhee did indeed find his style of his own. This work was followed by the Concerto for Wind Orchestra, which was performed for the first time by The American Wind Symphony under the general direction of Robert Austin Boudreau. In this piece, McPhee used pentatonic scales that he learned about through Balinese music. It was a difficult task to adapt the characteristic sound of gamelan for western wind instruments, but Concerto for Wind Orchestra was widely held as a successful piece.

In 1960, Colin McPhee became a professor at the University of California Los Angeles, specializing in composition, orchestration, Indonesian music, and Balinese

\footnotetext{
${ }^{13}$ See also "Distant Tones", excerpts from the Bali field notes of Colin McPhee, Edited and with an introduction by Carol J. Oja, with five linocut prints by William Rueter, 1990.
} 
compositional technique. He shared his great experience with Balinese music as well as his great knowledge in western music with his students at UCLA, until he resigned from in 1963 to complete work on his book on Balinese music.

McPhee's life ended in both triumph and tragedy in 1964, only a few weeks after finishing his magnum opus Music in Bali (Tenzer, 1998: 17). This book was an exhaustive attempt to explore all aspects of Balinese music. It was published two years after his death with the help of Dr. Mantle Hood, a professor of the University of California Los Angeles. He had begun writing it in 1930, and had worked on it consistently since then. This is an important and useful book that provides a lot of great musical and pictorial illustrations of Balinese musicians and dancers, giving an obvious picture of the customs of Bali. The way that McPhee gives a description about many different types of ensemble that are appear in Bali is really clear and supplemented by transcriptions and photographs documentation. He also gives useful selective list of musical transcriptions of the music of Bali, made before 1930s until the time of its publication, available at the University of California Los Angeles. Generally, this book gives a better idea and insight about the scene of Balinese society, the music, dance, and religion as well as the custom of Bali.

William P. Malm reviewed McPhee's book in The Journal of Ethnomusicology (Malm, 1967: 719-720). In his review, he said that this is a major result of McPhee's effort. He worked with great diligence and talent at forming some permanent record of the traditions in order to preserve many different older forms of Balinese music, which he thought, soon would be extinct. Malm continued to say that this book also provides wide information with an impressive synthesis of the music of Bali, musical performance practice, and the place of music in Balinese life some thirty years ago. On the other hand, Richard A. Waterman said in his review for this book, that the remainder of the central portion of the book is musicology and perhaps too technical in spots for non-musicologist. It was hard for anyone to understand the explanation of the music by only looking at the musical scores provided in the book. However, Waterman was amazed at what McPhee had been done with his field technique in 
the days before recording equipment was available. This book also provide an old and new music of Bali, which are presented, described, and analyzed with all respect to Jaap Kunst's 1925 pioneer study (Waterman, 1967: 766).

As Mantle Hood says in his foreword to the book, "the achievement of such magnum opus did not come about casually" (McPhee, 1966: v). This work represents a great and strong desire of a young composer who wanted to find the source of the sound that he was dreamed of. The exotic sound of Balinese music becomes aesthetic sounds that attracted him and completely change his life. This book has an interesting subject matter, the physical of the book is large because it provides a lot of detail information about the subject that was arrange in a tasteful, impressive, and beautiful way.

\section{CLOSING}

Colin McPhee was a talented pianist and composer who had a deep musicological interest in exploring another musical language. Only a few composers in the western world would have afforded themselves the chance to do exactly the same thing that McPhee did. His life was completely changed by the influence of Balinese music. He published books about music and culture of Bali as well as the aspect of human life in Balinese society. In fact, McPhee's works engaging in and focusing on Balinese culture are a great contribution to the Balinese and a good way of introducing Balinese culture to the world. For the present and future generations of Balinese musicians, McPhee's works of Balinese music will be standing as an important piece of heritage.

\section{BIBLIOGRAPHY}

Friedheim, Arthur. 1961. Life and Liszt. The Recollections of a Concert Pianist. New York: Taplinger Publishing Pub. Co.

Malm, P William. 1967. Reviewed Works of Music In Bali, A Study of Form and Instrument Organization in Balinese Orchestral Music, by Colin McPhee, Notes, $2^{\text {nd }}$ Series, Vol. 23, No. 4, pp. 719-720.

McPhee, Colin. 1972. A House in Bali. John Day, New York, 1946; reprinted by 
Oxford in Asia.

McPhee, Colin. 1960. Tabuh-tabuhan: Toccata for Orchestra and 2 Pianos/Colin McPhee, New York: Associated Music, Distributed by Hal Leonard.

McPhee, Colin. 1948. A Club of Small Men. New York: John Day.

McPhee, Colin. 1966. Music in Bali; A Study of Form and Instrumental Organization in Balinese Orchestral Music. New Haven and London, Yale University Press.

Oja, Carol J. 1984. Colin McPhee: A Composer Turned Explorer, Tempo, New Series, No. 148. pp. 2-7.

Oja, Carol J. 1990. Colin McPhee: Composer in Two Worlds, Washington and London: Smithsonian Institute Press, p. 353. https: //eamusic.dartmouth.edu/ larry/misc writings/out of print/mcphee.rev.html (date accessed: October 12, 2007).

Oja, Carol J. 1990. Distant Tones, an Excerpt from the field notes of Colin McPhee, By the Estate of Colin McPhee, The Aliquando Press.

Tenzer, Michael. 1998. Balinese Music, Periplus Edition, (HK) Ltd.

Tenzer, Michael. 2000-2001. Reviewed Works of Britten and the Far East: Asian Influences in the Music of Benjamin Britten by Mervyn Cooke, Asian Music, Vol. 32, No. 1, Tribal Music of India, pp. 190-192.

UCLA Archive, Colin McPhee Collection. http://www.ethnomusic.ucla.edu/Archive/mcphee.htm (date accessed: October 14, 2007).

Young, Douglas. 1984. Colin McPhee: (I) From West to East, Tempo, New Series, No. 150. pp 11-17.

Young, Douglas. 1986. Colin McPhee's Music: (II) 'Tabuh-tabuhan', Tempo, New Series, No. 159, pp 16-19.

Waterman, A. Richard. 1967. Reviewed Works of Music In Bali, A Study of Form and Instrument Organization in Balinese Orchestral Music, by Colin McPhee, American Anthropologist, New Series, Vol. 69, No. 6, p. 766.

\section{Audio Recordings}

McPhee, Colin. 1960. Tabuh-tabuhan, AMP Inc. 1 LP disc: analog, 33 1/3 r/m ; 30 $\mathrm{cm}$.

McPhee, Colin. 1996. Symphony no. 2; Concerto for piano with wind octette; Nocturne for chamber orchestra; Balinese ceremonial music, Published by Oakhurst, NJ: Music Masters Classic (LP disc). 